\title{
Potensi Gugus PAUD untuk Pembinaan Paska Pelatihan Pendidik Anak Usia Dini dengan Menggunakan Lesson Study
}

\author{
Ikka Kartika Abbas Fauzi \\ Pendidikan Luar Sekolah, Universitas Islam Nusantara. Jalan Soekarno Hatta No.53o, Sekejati, \\ Buahbatu, Kota Bandung, Jawa Barat 40286, Indonesia \\ Email: ikka28kaf@yahoo.com
}

Received: 17 August 2016; Revised: 22 March 2017; Accepted: 23 March 2017

\begin{abstract}
Abstrak
Penelitian ini bertujuan untuk mencari peluang bagi peningkatan kompetensi pendidik PAUD paska pelatihan dengan menggunakan lesson study melalui wadah pembinaan yang sudah ada, yaitu Gugus PAUD. Alasannya hanya 20,4 \% tenaga pendidik alumni Diklat yang langsung mampu menerapkan hasil pelatihannya. Di sisi lain, banyak Gugus PAUD yang belum optimal dimanfaatkan sebagai wadah pembinaan pendidik PAUD. Penelitian ini menggunakan metoda kualitatif dengan teknik pengumpulan data wawancara, observasi dan dokumentasi. Data dianalisis dengan menggunakan flow model. Hasil penelitian menunjukkan bahwa Gugus PAUD memiliki peluang untuk mengembangkan pembinaan Paska Pelatihan dengan menggunakan model pembinaan Lesson Study karena memiliki potensi yang relevan dengan penyelenggaraan lesson study, yaitu: terstruktur dan terorganisir, pembinaan terus menerus dari pihak yang berwenang, kebersamaan, pendekatan partisipatif, kemampuan bermitra dan penumbuhan komunitas belajar. Dalam pelaksanaannya perlu memperhatikan factor pendorong dan penghambat pembinaan di Gugus PAUD.
\end{abstract}

Kata Kunci: potensi gugus PAUD, lesson study, pembinaan pasca pelatihan

\section{Potential Gugus PAUD for Coaching Post Training Early Childhood Educators by Using Lesson Study}

\begin{abstract}
This study aims to explore opportunities for increased competence post training early childhood educators with using lesson study through the existing institution, namely Gugus PAUD. The reason only $20.4 \%$ of educators alumnus of training that is directly able to apply their training. On the other hand, many Gugus PAUD that has not been optimally utilized as a forum for coaching early childhood educators. This study uses qualitative methods with data collection techniques of interview, observation and documentation. Data were analyzed using flow model . The results showed that the Gugus PAUD has the opportunity to develop coaching after the training using coaching model Lesson Study as it has potential relevance for the implementation of lesson study, namely: structured and organized, coaching continuously from the authorities, togetherness, participatory approach, the ability to partner and growth of a learning community. In the execution should also pay attention to supporting factors and inhibiting factors in Gugus PAUD development.
\end{abstract}

Keywords: potential Gugus PAUD, lesson study, post-training coaching

How to Cite: Fauzi, I. (2017). Potensi gugus PAUD untuk pembinaan paska pelatihan pendidik anak usia dini dengan menggunakan lesson study. Jurnal Pendidikan dan Pemberdayaan Masyarakat, 4(1), 37-50. doi:http://dx.doi.org/10.21831/jppm.v4i1.10479

Permalink/DOI: http://dx.doi.org/10.21831/jppm.v4i1.10479 


\section{Jurnal Pendidikan dan Pemberdayaan Masyarakat, 4 (1), March 2017 - 38}

Ikka Kartika Abbas Fauzi

\section{PENDAHULUAN}

Pelatihan merupakan salah satu upaya memodifikasi atau mengembangkan pengetahuan, keterampilan dan sikap melalui pengalaman belajar untuk mencapai hasil yang efektive dalam aktivitas kerjanya (Buckley \& Caple, 2009, p. 9). Kemampuan ini diperoleh melalui proses tertentu sesuai tujuan perubahan yang yang ingin diperoleh atau yang diharapkan oleh peserta pelatihan. Prosesnya diawali sejak sebelum proses pelatihan (melalui need assessment), pada saat pelatihan dan sesudah proses pelatihan.

Hal ini berlaku juga bagi pendidik Pendidikan Anak Usia Dini (PAUD), terutama PAUD jalur pendidikan nonformal, dituntut untuk selalu meningkatkan kompetensinya melalui pelatihan karena masih banyak diantara mereka belum memiliki kompetensi dan kualifikasi sesuai dengan ketentuan. Dalam Undang-undang Pendidikan Nasional No. 20 tahun 2003 Pasal 28 ditegaskan bahwa penyelenggaraan PAUD dilakukan melalui jalur formal, non formal dan informal. Jalur formal berbentuk Taman Kanak-kanak (TK), Raudatul Athfal (RA), atau bentuk lain yang sederajat. Jalur pendidikan nonformal berbentuk Kelompok Bermain (Kober atau KB), Taman Penitipan Anak (TPA), atau bentuk lain yang sederajat. Jalur pendidikan informal berbentuk pendidikan keluarga atau pendidikan yang diselenggarakan oleh lingkungan.

Menurut Asolihin. (2013), Jalur formal, yaitu TK, telah dikenal sejak penjajahan Belanda, penjajahan Jepang hingga saat ini. Pengakuan pemerintah sudah sejak lama diberikan yaitu melalui UU No. 4 tahun 1950 tentang Dasar-dasar Pendidikan dan Pengajaran di Sekolah. Keberadaan TK resmi diakui sebagai bagian dari sistem pendidikan nasional. Pada tanggal 22 Mei 1950 berdiri Ikatan Guru Taman Kanak-kanak Indonesia (IGTKI). Sementara itu PAUD jalur non formal baru dikenal banyak orang sejak belasan tahun terakhir, terutama sejak dikeluarkannya Undang-undang no. 20 Tahun 2003 tentang Sistem Pendidikan Nasional yang isinya antara lain mengakui keberadaan PAUD jalur pendidikan nonformal dalam bentuk Kelompok Bermain (KB), Taman
Penitipan Anak (TPA) dan satuan PAUD Sejenis (SPS) dalam bentuk pengintegrasian layanan PAUD dengan Posyandu atau biasa disebut POSPAUD.

Tumbuh dan berkembangnya kedua jalur ini dalam waktu yang berbeda cenderung dianggap berdampak terhadap kinerja para pendidiknya karena adanya kesenjangan dalam pengalaman, kemampuan dan latar belakang pendidikan. Sebagai jalan keluarnya, sejak tahun 2010 pemerintah mengeluarkan kebijakan tentang penggabungan pembinaan PAUD formal dan PAUD nonformal di bawah Direktorat Jenderal Pendidikan Anak Usia Dini, Nonformal dan Informal (PAUDNI) melalui Peraturan Presiden Nomor 24 tahun 2010 tentang Kedudukan, Tugas, Fungsi dan Tata Kerja Kementrian Negara Republik Indonesia sebagaimana diubah dengan Peraturan Presiden Nomor 67 Tahun 2010. Pada awal tahun 2011 pemerintah menggagas Pembentukan dan Pembinaan Gugus PAUD di seluruh Indonesia sebagai wadah yang dapat menjembatani kesenjangan kompetensi dan kualifikasi pendidik PAUD sehingga mereka dapat memberikan layanan maksimal kepada peserta didiknya.

Di sisi lain, peningkatan kompetensi dan kapasitas pendidik PAUD melalui pelatihan atau pendidikan dan pelatihan, telah diselenggarakan oleh berbagai pihak, namun, untuk mengimplementasikan hasil pelatihan ini bukanlah hal yang mudah. Hasil penelitian awal di Kabupaten Sumedang dan Kota Bandung, ternyata setelah selesai pelatihan hanya hanya 20,4\% tenaga pendidik/alumni Diklat yang langsung mampu menerapkan hasil pelatihannya dalam kegiatan pembelajaran PAUD, 20,8 \% baru mampu menerapkan sebagian dan $58,8 \%$ sama sekali tidak menerapkan.

Kondisi ini diduga karena tidak semua penyelenggara pelatihan melakukan kegiatan paska pelatihan. Padahal evaluasi hasil pelatihan terutama dilakukan saat proses pelatihan dan sesudah proses pelatihan, melalui evaluating reaction, evaluating learning, evaluating behavior dan evaluating result (Kirkpatrick \& Kirkpatrick, 2006). Ternyata kegiatan paska pelatihan baru dirasakan oleh $23,3 \%$ pendidik PAUD, sebesar $15 \%$ menga- 
takan tidak tahu dan sisanya $71,70 \%$ menyatakan tidak ada pembinaan paska pelatihan. Hasil ini tidak jauh berbeda dengan hasil penelitian Muttaqin, F. (2011) terhadap 150 orang alumni Diklat dasar PAUD, bahwa hanya 32,92 \% yang mampu menerapkan hasil Diklat yang berkaitan dengan kompetensi Profesional dan kompetensi paedagogis. Kondisi di lingkungan kerja para pendidik PAUD pun kadang-kadang kurang mendukung penerapan hasil pelatihan sehingga melemahkan motivasi pendidik PAUD untuk meningkatkan kompetensi dirinya. Alhasil penguatan kompetensi yang diperoleh pendidik melalui Diklat belum bisa berkembang secara optimal.

Gugus PAUD merupakan wadah yang tepat untuk mengatasi kesulitan pendidik dalam menerapkan hasil pelatihan karena memiliki fungsi sebagai wadah pembinaan pendidik PAUD. Namun, hasil pengamatan di lapangan menunjukkan bahwa belum semua daerah memiliki Gugus PAUD dan jika ada daerah yang memilikinya, belum semuanya mampu berfungsi dengan baik.

Beranjak dari latar belakang tersebut, maka permasalahan dalam penelitian ini difokuskan pada aspek-aspek seperti terlihat dalam Gambar 1.

\section{METODE}

Penelitian ini bertujuan untuk mengeksplorasi kondisi Gugus PAUD yang sebenarnya secara mendalam sehingga digunakan pendekatan kualitatif. Data diperoleh melalui in-depth interviews terhadap 39 orang yang berkaitan dengan penyelenggaraan pembinaan Gugus PAUD dan melalui observasi terhadap kegiatan Gugus PAUD. Mereka dipilih berdasarkan purposive sampling, berasal dari Gugus PAUD di Kecamatan Mandalajati Kota Bandung, Gugus PAUD di Kecamatan Sumedang Utara dan Gugus PAUD di Kecamatan Rancakalong, keduanya berada di Kabupaten Sumedang. Dipilihnya tiga kecamatan ini didasarkan pada alasan berikut ini. Pertama, karena pendidik PAUD yang ada di Gugus ini berasal dari PAUD jalur formal dan jalur non formal. Kedua, gugus mampu mengintegrasikan kedua jalur itu dalam melaksanakan program-programnya. Ketiga, gugus-gugus ini mampu mengembangkan program yang menjadi kewajibannya.

Untuk membantu pengumpulan data peneliti menggunakan semi-structured interview guide serta observasi non participant. Analisis data menggunakan flow model dari Miles dan Huberman, yaitu dengan aktivitas data reduction, data display dan conclusion drawing/ verifikation yang dilakukan secara interaktif dan terus menerus sampai tuntas, selama pengumpulan data maupun setelah data terkumpul hingga datanya jenuh. Adapun sumber data utama terdiri dari berbagai pihak yang berkaitan dengan penyelenggaraan Gugus PAUD.

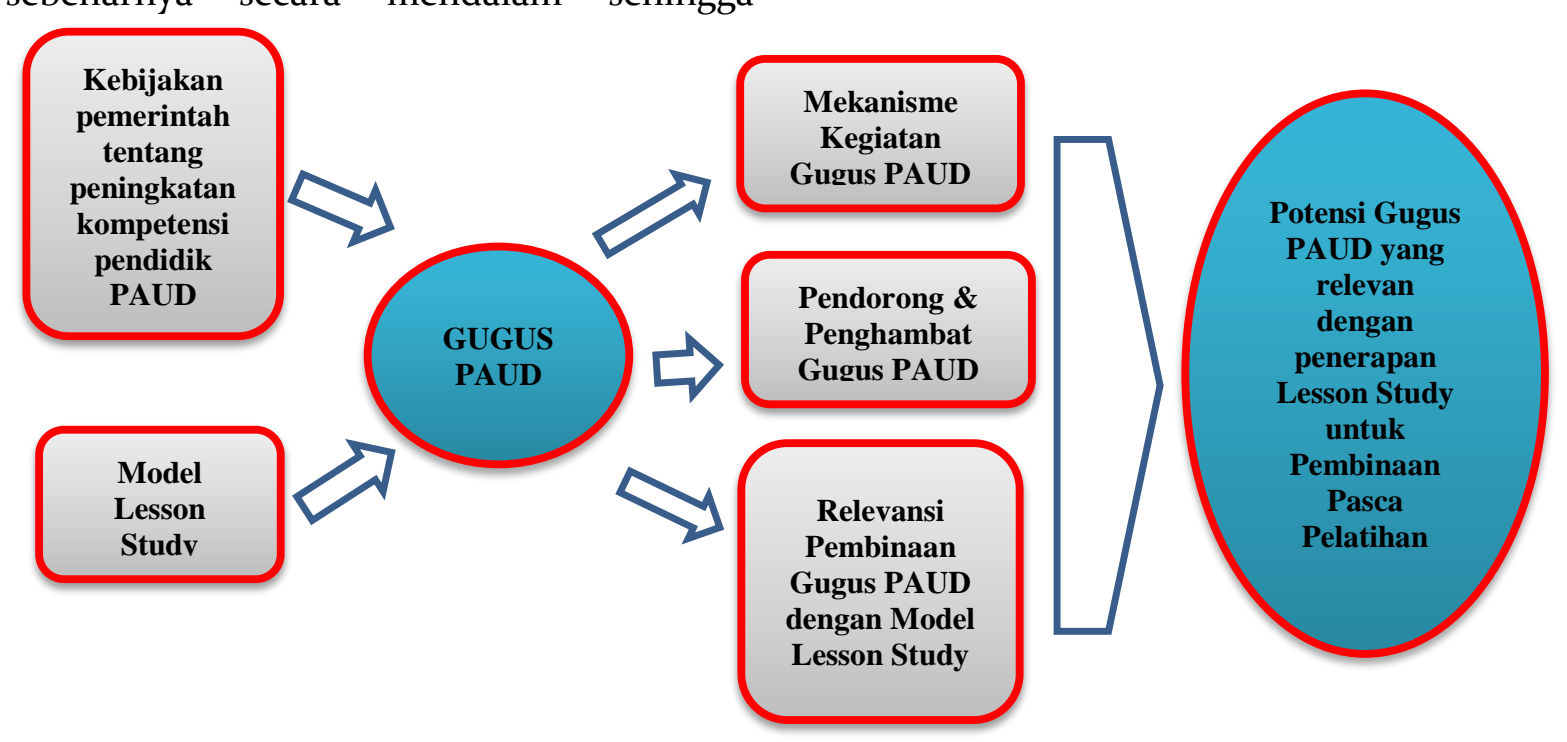

Gambar 1. Kerangka Penelitian 
Jurnal Pendidikan dan Pemberdayaan Masyarakat, 4 (1), March 2017 - 40

Ikka Kartika Abbas Fauzi

Tabel 1. Sumber Data Utama

\begin{tabular}{lccc}
\hline \multicolumn{1}{c}{ Sumber data } & $\begin{array}{c}\text { Kecamatan } \\
\text { Mandalajati }\end{array}$ & $\begin{array}{c}\text { Kecamatan } \\
\text { Sumedang Utara }\end{array}$ & $\begin{array}{c}\text { Kecamatan } \\
\text { Rancakalong }\end{array}$ \\
\hline Pendidik PAUD Formal & 3 orang & 3 orang & 3 orang \\
Pendidik PAUD Non formal & 6 orang & 6 orang & 6 orang \\
Kepala Sekolah PAUD Formal \& Non Formal & 2 orang & 2 orang & 2 orang \\
Pengurus Gugus PAUD & 2 orang & 2 orang & 2 orang \\
JUMLAH & 13 orang & 13 orang & 13 orang \\
\hline
\end{tabular}

Sumber: hasil penelitian

Sumber data pendukung diperoleh

dari Pengurus PKG Kecamatan, Penilik

PAUD, Pengawas TK dan Kepala Seksi PAUD

Dinas Pendidikan Kabupaten/Kota. Sumber data sekunder akan diperoleh dari dokumentasi yang berkaitan dengan manajemen pengelolaan Gugus PAUD, pembinaan pendidik PAUD, laporan program kegiatan yang selama ini dilaksanakan, dan lain-lain.

\section{HASIL DAN PEMBAHASAN}

\section{Kebijakan Pemerintah}

Dalam Rencana Pembangunan Jangka Menengah (RPJM) Nasional 2004-2009 program PAUD menjadi salah satu prioritas Pembangunan Nasional. Beberapa produk hukum yang telah mengamanatkan pembinaan kompetensi bagi pendidik PAUD, yaitu: Pertama, undang-undang No.20 tahun 2003, pada pasal 44 ayat (1) dan (3) menyatakan bahwa Pemerintah dan Pemerintah Daerah wajib membina dan mengembangkan tenaga kependidikan pada satuan pendidikan yang diselenggarakan oleh Pemerintah dan Pemerintah Daerah dan membantu membina dan mengembangkan tenaga kependidikan pada satuan pendidikan yang diselenggarakan oleh masyarakat. Kedua, Peraturan Pemerintah No.19 tahun 2005 tentang Standar Pendidikan Nasional pasal 28 ayat (3) menyatakan bahwa "Kompetensi sebagai agen pembelajaran pada jenjang pendidikan dasar dan menengah serta pendidikan anak usia dini meliputi kompetensi pedagogik, kompetensi kepribadian, kompetensi professional dan kompetensi social". Ketiga, Peraturan Menteri Pendidikan Nasional (Permendiknas) Nomor. 58 tahun 2009 tentang Standar PAUD (formal dan nonformal), yang berisi tentang: (1) Standar tingkat pencapaian perkembangan; (2) Standar pendidik dan tenaga kependidik-

an; (3) Standar isi, proses, dan penilaian; dan (4) Standar sarana dan prasarana, pengelolaan, dan pembiayaan. Keempat, Peraturan Pemerintah No. 17 tahun 2010 tentang Pengelolaan dan Penyelenggaraan Pendidikan, pasal 176 ayat (4) menyatakan bahwa "Pembinaan karier pendidik dilaksanakan dalam bentuk peningkatan kualifikasi akademik dan/atau kompetensi sebagai agen pembelajaran dengan mengacu pada Standar Nasional Pendidikan".

Pada tahun 2009, data menunjukan bahwa pendidik PAUD yang mengikuti peningkatan kompetensi hanya $7 \%$ (Renstra 2010-2014). Kondisi ini berpengaruh terhadap Angka Partisipasi Kasar (APK) PAUD yaitu hanya sebesar $43,73 \%$. Ini disebabkan karena belum optimalnya pelaksanaan PAUD nonformal dan informal terutama dalam memberikan layanan pengembangan anak usia o-6 tahun, masih kurangnya pendidikan orang tua dalam hal pengasuhan anak (parenting education). Oleh karena itu dalam Rencana Strategi 2010-2014 diharapkan pendidik PAUD yang mengikuti peningkatan kompetensi meningkat menjadi 44,63\% dan APK PAUD menjadi 72,00 \%.

Untuk melaksanakan rencana strategis tersebut, peningkatan kompetensi pendidik PAUD diperluas daya jangkaunya dan bentuk kegiatannya. Pada tahun 2011 tercatat sebanyak 17 training provider diberi bantuan oleh Ditjen PAUDNI untuk menyelenggarakan pelatihan pendidik PAUD. Lembaga tersebutterdiri dari: (1) Asosiasi (HIMPAUDI, IGTKI, BPTKI); (2) Organisasi Sosial Masyarakat (Aisyiah, Muslimat NU, WI); (3) Unit Pelaksana Teknis /Unit Pelaksana Teknis Daerah (P2PNFI, BPPNFI, BPKB, SKB) dan (4) Perguruan Tinggi. Bentuk kegiatan peningkatan kompetensi pun beragam, terdiri dari: Diklat berjenjang, magang, kursus, forum ilmiah/seminar/workshop. Penyeleng- 


\section{Jurnal Pendidikan dan Pemberdayaan Masyarakat, 4 (1), March 2017 - 41}

Ikka Kartika Abbas Fauzi

garaannya dilaksanakan di tingkat pusat, provinsi dan kabupaten/kota. Program ini dilaksanakan lagi pada tahun-tahun berikutnya dengan jumlah training provider yang semakin meningkat.

Di masyarakat, terdapat training provider yang sepenuhnya menggunakan dana mandiri, misalnya Lembaga Kursus dan Pelatihan (LKP), organisasi social, Lembaga Sosial Masyarakat (LSM), bahkan kelompokkelompok kecil/individual yang memiliki kepedulian terhadap pengembangan PAUD. Beberapa training provider yang diberi bantuan Ditjen PAUDNI juga menyelenggarakan peningkatan kompetensi pendidik PAUD dengan dana mandiri dalam rangka memperluas jangkauan pelayanan.

Pedoman pelatihan training provider yang didanai Ditjen PAUDNI Kemdiknas, penyelenggaraan pelatihannya mengacu pada Pedoman Pendidikan dan Pelatihan (Diklat) berjenjang Ditjen PAUDNI Kemdiknas, yang terdiri dari Diklat Tingkat Dasar (48 jam tatap muka dan 200 jam pelatihan atau jampel tugas mandiri), kemudian Diklat Tingkat Lanjutan (64 jampel tatap muka dan 200 jampel tugas mandiri) dan terakhir Diklat Tingkat Mahir (8o jampel tatap muka dan 200 jampel tugas mandiri). Tugas mandiri 200 jampel dilakukan selama 25 hari kerja atau kurang lebih satu bulan). Diklat yang diselenggarakan oleh perguruan tinggi waktunya antara 90-980 jampel dan materinya lebih dikembangkan lagi karena untuk mempersiapkan peserta yang akan meningkatan kualifikasi melalui program konversi. Sementara itu, Diklat yang diselenggarakan secara swadana oleh masyarakat, baik oleh lembaga perorangan atau non lembaga, materi dan waktu kegiatan tidak sepenuhnya mengacu pada panduan Ditjen PAUDNI tapi mengacu pada kebutuhan lapangan atau permintaan calon peserta.

Kegiatan peningkatan kompetensi tersebut diiringi juga dengan kebijakan lainnya yaitu Pembentukan dan Pembinaan Gugus PAUD di seluruh Indonesia (tahun 2011). Gugus PAUD adalah wadah strategis yang akan menjembatani kesenjangan latar belakang pendidikan, pengalaman, kemampuan tenaga pendidik PAUD. Wadah ini yang dibangun dari, oleh, dan untuk pendidik dan tenaga kependidikan PAUD. Kepengurusan, program, dan bentuk kegiatan direncanakan, dikembangkan, dan dilaksanakan untuk memenuhi kebutuhan peningkatan profesi pendidik sesuai dengan kebutuhan anggota. Wadah ini bisa disebut juga sebagai peergroup mentoring yaitu suatu "model of supporting professional development" yang difocuskan pada guru (Geeraerts et al., 2015, p. $\mathrm{xv}$ ). Pusat Kegiatan Gugus (PKG) di tingkat Kecamatan menjadi basecamp informasi yang terkait dengan upaya pembinaan dan peningkatan layanan PAUD untuk ditindaklanjuti oleh gugus PAUD. Dinas Pendidikan Kabupaten/Kota berperan selaku Pembina yang pelaksanaannya di tingkat kecamatan dilakukan oleh UPTD. Kepala UPTD menjadi Pembina Administrasi, sedangkan Penilik PAUD dan Pengawas TK selaku Pembina Teknis.

\section{Pembinaan Pasca Pelatihan}

Training provider yang didanai Ditjen PAUDNI Kemdiknas belum semuanya mampu menyelenggarakan 200 jampel tugas mandiri atau 25 hari kerja sebagai kegiatan paska pelatihan. Ada yang dimonitor secara serius kemudian dilanjutkan dengan laporan hasil tugas mandiri atau dengan tes akhir, namun ada pula yang menyerahkan kegiatan monitoring sepenuhnya kepada kepala sekolah tempat peserta pelatihan bekerja. Bagi Diklat yang diselenggarakan secara swadana oleh masyarakat, kegiatan pasca pelatihan ini seringkali tidak dijadwalkan karena identik dengan pengeluaran dana tambahan. Sementara itu, Diklat yang diselenggarakan oleh perguruan tinggi, pembinaan pasca pelatihan bagi peserta yang mengikuti program konversi dilanjutkan melalui program perkuliahan. Bagi yang tidak mengikuti perkuliahan, pembinaan pasca pelatihan dilakukan melalui Diklat Lanjutan, melalui pendampingan dalam jangka waktu tertentu atau hanya konsultasi.

Pelatihan dikatakan berhasil jika peserta mampu memperoleh pengetahuan, skill serta attitude yang dibutuhkan untuk meningkatkan kinerjanya serta memiliki peluang untuk menerapkan hasil pelatihan sehingga dapat meningkatkan produktifitas dan kinerja lembaga tempatnya bekerja 


\section{Jurnal Pendidikan dan Pemberdayaan Masyarakat, 4 (1), March 2017 - 42}

Ikka Kartika Abbas Fauzi

(Buckley \& Caple, 2009, p. 15; Kirkpatrick \& Kirkpatrick, 2006, pp. 28 \& 34; Sudjana, 2001). Namun, dari 39 orang sumber data, hanya 7 orang pendidik PAUD formal dan 5 orang pendidik PAUD Non formal yang mampu langsung dapat menerapkan sebagian hasil pelatihannya. Pendidik PAUD formal mampu melakukan itu karena mereka minimal sudah 8 tahun menjadi pendidik PAUD dan berlatar belakang pendidikan Sekolah Pendidikan Guru TK (SPG-TK) atau Program D2 Pendidikan Guru TK (PGTK). Tujuan mereka mengikuti pelatihan adalah untuk menambah wawasan tentang perkembangan pembelajaran PAUD saat ini. Alasan pendidik PAUD non formal memiliki keberanian untuk mencoba menerapkan hasil pelatihan karena rata-rata sudah 2-3 kali mengikuti pelatihan serupa dan berlatar belakang pendidikan keguruan serta diberi kesempatan oleh kepala sekolah untuk menerapkannya.

Selanjutnya, sebanyak 5 orang pendidik PAUD formal dan 4 orang pendidik PAUD Non formal baru mampu menerapkan sebagian kecil hasil pelatihan. Alasan pendidik PAUD Formal karena latar belakang pendidikan mereka bukan dari pendidikan keguruan walaupun mereka sudah mengajar minimal 6 tahun. Mereka masih belum memahami secara mendalam tentang teoriteori kependidikan maupun psikologi perkembangan anak sehingga merasa belum menguasai keterampilan yang telah dipelajarinya melalui pelatihan, padahal temanteman maupun kepala sekolahnya mau membantu. Sementara itu, alasan pendidik PAUD non formal karena kepala sekolah kurang mengijinkan dan sarana prasarana serta dana sekolah kurang memungkinkan untuk menerapkan hasil pelatihan.

Selanjutnya, 18 orang pendidik PAUD Non Formal, sama sekali belum menerapkan hasil pelatihan. Kondisi ini terjadi karena berbagai factor, yaitu: Pertama, waktu pelatihan yang diikuti pendidik PAUD pada umumnya relative kurang. Hanya dua orang yang pernah mengikuti pelatihan selama 4-6 hari, sisanya hanya mengikuti pelatihan selama 1-3 hari. Waktu ini relative singkat jika peserta dituntut untuk meningkatkan kompetensinya, karena dalam satu hari mereka hanya memiliki waktu efektif untuk menerima materi pelatihan sekitar 8 jam pelatihan (jampel). Jika satu jampel 50 menit, mereka hanya memiliki 400 menit sehari atau sekitar 6,67 jam/hari. Karena pelatihan ini untuk meningkatkan kompetensi peserta, terutama kompetensi pedagogik dan professional yang banyak memerlukan praktek, maka waktu 3 atau 5 hari (sekitar 20,01 jam atau 33,35 jam) sangat kurang untuk memperoleh keterampilan tingkat dasar yang memerlukan minimal 6 materi. Misalnya jika waktu hanya 3 hari dengan rata-rata 6 materi, maka setiap materi hanya memperoleh 3,33 jam. Oleh karena itu ada kecenderungannya mereka tahu tapi tidak paham cara menerapkannya.

Kedua, pembinaan paska pelatihan. Hanya sekitar 7 orang pendidik PAUD yang menyatakan ada pembinaan pasca pelatihan, sekitar 4 orang mengatakan tidak tahu ada pembinaan paska pelatihan dan sisanya 28 orang menyatakan tidak ada pembinaan paska pelatihan. Namun, motivasi mereka sangat tinggi sehingga tidak putus asa bahkan menghubungi orang-orang yang ada di sekitarnya, yang dianggap mampu menjelaskan. Coombes (2011) mengatakan bahwa: "Motivation and peak performance come from knowing what you want to achieve in life ..... We might say we want a better job, partner or home, but our mine is to get away from our current situation" Coombes (2011). Sebanyak 6 orang pendidik PAUD meminta penjelasan dari Penilik PAUD atau Pengawas TK yang dianggap tahu tentang seluk beluk pembelajaran di PAUD. Sebanyak 6 orang pendidik meminta penjelasan dari teman-temannya karena kurang mengenal dekat Penilik PAUD atau Pengawas TK dan malu jika harus bertanya pada Kepala Sekolahnya. Sebanyak 9 orang pendidik meminta penjelasan dari ketua atau pengurus Gugus PAUD karena para pengurus ini sebenarnya temantemannya juga yang sudah dikenalnya cukup lama. Sebanyak 6 orang pendidik PAUD meminta penjelasan dari Kepala Sekolahnya karena kepala sekolahnya memberi kesempatan mereka untuk mencoba menerapkan hasil pelatihan. Hanya satu orang yang langsung meminta penjelasan dari nara sumber 
pelatihan karena kebetulan kakaknya kenal dengan nara sumber tersebut.

Dari upaya para pendidik tersebut nampak bahwa kedekatan merupakan alasan utama mereka untuk meminta penjelasan. Namun, upaya inipun nampaknya kurang efektif karena Penilik PAUD tidak selalu memahami dan mampu mempraktekan materi pelatihan secara detail berhubung pada umumnya mereka tidak berlatar belakang pendidik PAUD. Lain halnya dengan Pengawas TK, sebagian besar dari mereka berasal dari pendidik TK. Kepala sekolah serta teman pun sebenarnya memiliki pengetahuan dan kecakapan yang tidak jauh berbeda dengan para pendidik PAUD. Sebaliknya dengan pengurus Gugus PAUD, mereka memiliki pengetahuan dan kemampuan yang lebih banyak dibanding pendidik PAUD karena mereka sering mengikuti pelatihan serupa atas inisiatif sendiri.

Ketiga, latar belakang pendidikan peserta, sebanyak 26 orang pendidik PAUD lulusan SLA non kependidikan dan sebanyak 13 orang adalah ulusan D1,D2, D3 dan S1 non kependidikan. Wajarlah jika mereka kesulitan untuk memahami pengetahuan dasar tentang kependidikan sehingga untuk menerapkan pengetahuan tersebut memerlukan waktu lama. Ruiz and Dams (2012, dalam Valerio, Parton, \& Robb, 2014, p. 44) menyebutkan bahwa "... note that the majority of high impact woman entrepreuneur (those who had a business growth of 2o percent or more over the preceding three years) had an educational attaintment level of college or above".

\section{Mekanisme Kegiatan Gugus PAUD}

Hasil penelitian menunjukkan bahwa kegiatan Gugus PAUD dilakukan secara partisipatif (Sumarto, 2004; Sudjana, 2001). Biasanya diawali dengan ide kegiatan yang berasal dari berbagai pihak, yaitu dari: pengurus PKG PAUD Kecamatan, pengurus
Gugus PAUD, PAUD Inti maupun PAUD Imbas, bahkan dari pendidik PAUD. Ide tersebut dibicarakan dalam rapat pengurus Gugus PAUD, jika disepakati disusun dalam bentuk program kegiatan. Pada saat penyusunan program, Ketua PKG PAUD, Penilik PAUD dan Pengawas TK diikutsertakan untuk diminta pendapatnya.

Pada saat pelaksanaan, seluruh pendidik PAUD dari Gugus Inti maupun Gugus Imbas diikutsertakan. Jika kegiatannya sangat penting untuk semua pendidik PAUD, kadang-kadang perwakilan dari IGTKI Kabupaten/Kota dan Himpaudi turut bekerjasama menyukseskan kegiatan tersebut. Evaluasi kegiatan didasarkan pada: (1) jumlah peserta kegiatan yang hadir dalam setiap kegiatan Gugus PAUD; (2) aktivitas peserta dalam setiap kegiatan Gugus PAUD; dan (3) variasi tempat kerja peserta (TK, RA, Kober, TPA, SPS ). Laporan kegiatan disampaikan kepada PKG PAUD, Pengawas TK dan Penilik PAUD serta Dinas Pendidikan Kabupaten/Kota.

Tindak lanjut kegiatan dilakukan melalui pertemuan lanjutan, kunjungan ke PAUD Imbas, atau bimbingan teknis. Materi tindak lanjut biasanya sesuai dengan tugas dan fungsi Gugus PAUD, namun yang paling sering dilakukan adalah kegiatan peningkatan kompetensi pedagogik dan professional, manajemen PAUD, manajemen Gugus PAUD, serta kegiatan-kegiatan lainnya yang berkaitan dengan anak usia dini. Disamping Dinas Pendidikan, kegiatan ini diselenggarakan atas kerjasama dengan lembaga pemerintah lainnya, seperti Dinas Kesehatan, Kepolisian, Dinas lingkungan hidup dan lain-lain. Hasil tindak lanjut ini misalnya berupa implementasi hasil kegiatan di tempat kerja peserta atau bertambahnya PAUD yang mengajukan akreditasi lembaga.

Berdasarkan hasil penelitian, mekanisme kegiatan Gugus PUD dapat dilihat pada Gambar 2. 


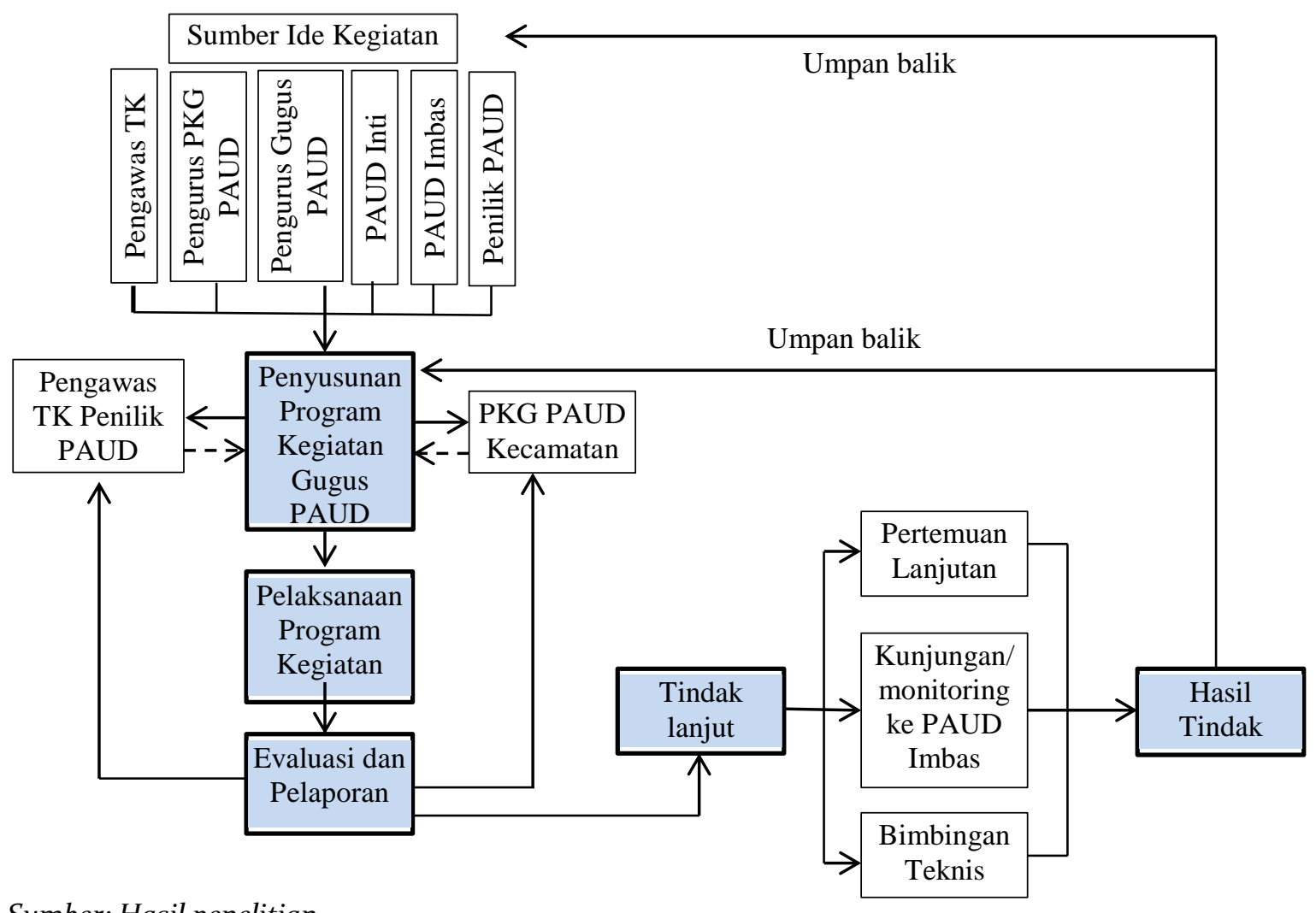

Sumber: Hasil penelitian

Gambar 2. Alur Pembinaan Gugus PAUD

\section{Pendorong dan Penghambat Pembinaan di Gugus PAUD}

Beberapa hal yang ditemukan dapat mendorong terlaksananya pembinaan pendidik melalui Gugus PAUD yaitu: (1) Dukungan pemerintah, dalam hal ini Dinas Pendidikan Kabupaten/Kota melalui Kepala UPTD di tingkat Kecamatan sebagai ujung tombaknya, memiliki andil yang sangat besar terhadap keberadaan dan keberlangsungan Gugus PAUD. Bimbingan dan motivasi yang terus menerus dilakukan Penilik PAUD dan Pengawas TK selaku Pembina Teknis Gugus PAUD, memberi kekuatan besar terhadap para pengurus Gugus PAUD untuk menjaga keberlanjutan kegiatan Gugus; (2) Sebagian pengurus Gugus PAUD berasal dari pengurus Himpaudi dan IGTKI. Kondisi ini berpengaruh positif terhadap kelancaran kegiatan gugus karena pengelolaan organisasi tidak terlalu berat sebab mereka sudah paham dengan kondisi pendidik PAUD di lingkungan organisasi profesinya, permasalahan serta kebutuhan-kebutuhannya dan sudah memiliki jaringan mitra kerja;
(3) Keikutsertaan pendidik PAUD dalam kegiatan Gugus merupakan suatu keharusan, karena tanpa keberadaan mereka kegiatan pembinaan tidak akan berlangsung. Keikutsertaan ini tumbuh karena ketepatan pendekatan yang dilakukan Dinas Pendidikan. Misalnya, di Kabupaten Sumedang, pada saat Gugus PAUD diperkenalkan, Dinas Pendidikan melakukan pendekatan berdasarkan data jumlah anak usia dini yang belum mengikuti PAUD disandingkan dengan jumlah PAUD formal (dalam hal ini TK) yang tersedia serta Undang-undang No.20 tahun 2003 tentang ketentuan usia PAUD Formal dan PAUD Non formal. Kesenjangan yang tinggi antara jumlah TK yang tersedia dengan jumlah anak usia dini yang harus dilayani, membuka mata semua pihak bahwa pelayanan PAUD harus dilaksanakan secara terintegrasi antara PAUD formal (TK) dengan PAUD Non formal, yaitu Kelompok Bermain, Pospaud dan SPS lainnya. Di lapangan, kebijakan ini ditindaklanjuti oleh pengawas TK dan penilik PAUD melalui upaya-upaya untuk membangun 
kerjasama yang baik antara pengurus yang berasal dari PAUD formal dan PAUD Non Formal sehingga mereka tidak punya alasan untuk saling berjauhan. Kedua kelompok ini akhirnya mampu berintegrasi dalam wadah Gugus PAUD; (4) Kondisi di lokasi penelitian menunjukkan bahwa sebanyak $73 \%$ pendidik PAUD mengajar di PAUD Non formal, yaitu $64.6 \%$ mengajar di Kelompok Bermain, 4.2\% mengajar di PosPAUD dan 4.2\% Satuan PAUD Sejenis (SPS) lainnya. Dari jumlah tersebut sebanyak 59.3\% berlatar belakang pendidikan SLTA dan 7,4 \% berpendidikan SLTP.Jumlah ini ditambah lagi dengan pendidik PAUD yang yang berlatar belakang D-1, D-2 dan D-3 non kependidikan/non PAUD sebesar 6,9 \% dan S-1 non kependidikan/Non PAUD sebesar 9,5 $\%$. Data ini dapat diartikan bahwa pendidik PAUD yang harus mendapat prioritas utama peningkatan kompetensi selaku pendidik adalah yang berlatar belakang pendidikan SLTP dan SLTA $(66,7 \%)$ serta yang berlatar pendidikan D-1, D-2, D-3 dan S-1 non kependidikan/non PAUD $(16,4 \%)$ ). Kondisi latar belakang pendidikan inilah yang menjadi motivasi besar bagi pendidik PAUD untuk ikutserta dalam kegiatan Gugus PAUD.

Hambatan penyelenggaraan terutama berkaitan dengan masalah waktu kegiatan yang dilaksanakan pada hari kerja, padahal penentuan waktu didasarkan pada kesepakatan bersama. Kenyataannya para pendidik PAUD tetap mengeluh karena pimpinan sekolah tidak mengijinkan seluruh pendidik meninggalkan tugas mengajar. Kondisi ini berdampak terhadap perolehan informasi. Mereka yang tidak hadir hanya memperoleh informasi dari tangan kedua yang penyampaiannya kadang-kadang kurang lengkap.

\section{Model Lesson Study}

Lesson study adalah model pembinaan profesi pendidik melalui pengkajian pembelajaran secara kolaboratif dan berkelanjutan berlandaskan prinsip-prinsip kolegalitas, dan mutual learning untuk membangun komunitas belajar atau learning community (IMSTEP-JICA. 2007, p. 10). Lesson study juga dinyatakan sebagai "Suatu metode analisis kasus pada praktik pembelajaran, ditujukan untuk membantu pengembangan profesional para guru dan membuka kesempatan bagi mereka untuk saling belajar berdasarkan praktik-praktik nyata di tingkat kelas (Depdiknas, Depag, JICA. 2009, p. 2). Menurut Lewis (2002, p. 1) lesson study adalah: "As we will see, lesson study is a cycle in which teachers work together to consider their long-term goals for students, bring those goals to life in actual "research lessons," and collaboratively observe, discuss, and refine the lessons.".

Lesson study ini diadopsi dari negara Jepang, dan di Indonesia penerapannya disesuaikan dengan kondisi Indonesia. Pelaksanaannya dapat berbasis sekolah maupun organisasi yang mewadahi pembinaan guruguru, seperti Musyawarah Guru Mata Pelajaran (MGMP) atau Kelompok Kerja Guru (KKG). Untuk Pusat Kerja Guru PAUD (PKG PAUD) nampaknya belum banyak yang melakukan karena PKG PAUD itu sendiri relative masih baru (sekitar 2011-2012) dan belum terbentuk di semua daerah.

Menurut Lewis, Perry and Hurd, (dalam Riyati, 2007), tujuan utama lesson study adalah untuk: (1) Meningkatkan pengetahuan tentang materi ajar; (2) Meningkatkan pengetahuan tentang pembelajaran; (3) meningkatkan kemampuan mengobservasi aktivitas belajar; (4) Semakin kuatnya hubungan Kolegalitas' (5) Semakin kuatnya hubungan antara pelaksanaan pembelajaran sehari-hari dengan tujuan jangka panjang yang harus dicapai; (6) Semakin meningkatnya motivasi untuk selalu berkembang; (7) Meningkatkan kualitas rencana pembelajaran.

Langkah Lesson study menurut Mulyana (2007) dilaksanakan dalam tiga tahapan yaitu Plan (Perencanaan), Do (pelaksanaan/implemenetasi) dan See (Refleksi) yang berkelanjutan, sehingga bisa dikatakan bahwa Lesson study merupakan cara peningkatan mutu pendidikan yang tidak pernah berakhir (continous improvement).

Cerbin \& Kopp (2004) dari University of Wisconsin menetapkan enam tahapan dalam Lesson study, terdiri dari: "(1) Form a Team: 3-6 people with similar teaching interests are identified; (2) Develop Student Learning Goals: Team members discuss what 


\section{Jurnal Pendidikan dan Pemberdayaan Masyarakat, 4 (1), March 2017 - 46}

Ikka Kartika Abbas Fauzi

they would like students to learn as a result of the lesson; (3) Plan the Research Lesson: Teachers design a lesson to achieve the learning goals, anticipating how students will respond; (4) Gather Evidence of Student Learning: One team member teaches the lesson while others observe, collecting evidence of student learning; (5) Analyze Evidence of Learning: The team discusses the results and assesses progress made toward learning goals; (6) Repeat the Process: The group revises the lesson, repeating steps 2-5 as necessary, and shares findings."

Firman \& Kaniawati (2007, pp. 7-10) mengemukakan indikator luaran hasil kegiatan lesson study yang bersifat fisik adalah: (1) Pengembangan silabus yang lengkap; (2) Pembelajaran yang terencana dalam bentuk RPP; (3) Teaching materials (handout, LKS); (4) Teaching media (media pembelajaran, sumber belajar); (5) Data input (peserta didik, guru, komunitas, lingkungan kerja); (6) Data proses (perencanaan, implementasi, dan refleksi); (7) Data output (kinerja guru, peningkatan kemampuan dan sikap pembelajar maupun pengajar, kegiatan laboratorium/studio, tanggapan pihak-pihak terkait); dan (8) Data evaluasi dampak (keberlanjutan).

\section{Relevansi Pembinaan Gugus PAUD dengan Model Lesson Study}

Terdapat beberapa potensi Gugus PAUD yang relevan dengan model lesson study sehingga dapat mendukung pembinaan pasca pelatihan. Potensi yang dimaksud adalah sebagai berikut: Pertama, terstruktur dan terorganisir. Lesson study adalah model pembinaan profesi pendidik yang kolaboratif, berkelanjutan, kolegalitas, mutual learning untuk membangun community learning atau komunitas belajar. Untuk menerapkan model pembinaan ini diperlukan wadah yang terstruktur dan terorganisir karena kegiatannya tidak hanya dilakukan sekalisekali tapi berkelanjutan agar terbangun komunitas belajar. Wadah yang terstruktur memiliki struktur kepengurusan dan pembagian tugas yang jelas serta memiliki legalitas serta pengakuan dari pihak yang berwenang. Terorganisir maksudnya memiliki visi, misi, tujuan dan program yang jelas dan aktif melaksanakan kegiatannya sesuai dengan langkah-langkah manajemen yang baik, yaitu melalui tahapan perencanaan, pelaksanaan, monitoring dan evaluasi serta pelaporan dan tindak lanjut. Gugus PAUD diinisiasi dan dibina oleh pemerintah secara legal. Organisasinya terstruktur dan penyelenggaraannya mengacu pada Buku Pedoman Pembinaan Gugus Pendidikan Anak Usia Dini yang ditetapkan oleh Kementerian Pendidikan Nasional, Direktorat Jenderal Pendidikan Anak Usia Dini Nonformal dan Informal, Direktorat Pembinaan Pendidikan Anak Usia Dini pada tahun 2011.

Kedua, pembinaan terus menerus dari pihak yang berwenang. Gugus PAUD dikembangkan oleh pemerintah dengan struktur yang jelas karena dikaitkan dengan struktur yang sudah berjalan sejak tingkat pusat hingga tingkat Kecamatan. Tugas pembinaan di masing-masing jenjang sebagai berikut: (1) Pembinaan gugus tingkat pusat dilakukan oleh Direktorat Pembinaan PAUD, yaitu dengan: (a) merumuskan kebijakan manajemen Gugus PAUD; (b) Pelaksanaan pembinaan secara berjenjang; (c) peningkatan kemitraan dengan organisasi penyelenggara PAUD, dan organisasi profesi dimana pendidik PAUD bernaung; (d) dukungan fasilitas penyelenggaraan Gugus PAUD; (2) Pembinaan melalui Gugus PAUD tingkat provinsi dilaksanakan oleh Dinas Pendidikan Provinsi dan Bidang Pendidikan Nonformal dan Informal yang menangani PAUD, dalam bentuk: (a) Pemantauan dan evaluasi pelaksanaan pembinaan dilapangan; (b) pengikutsertaan dan pengkoordinasian instansi/lembaga kependidikan yang relevan untuk menyumbangkan tenaga ahlinya; (c) Koordinasi kemitraan dengan organisasi penyelenggara PAUD, dan organisasi profesi dimana pendidik PAUD bernaung. (3) Pembinaan Gugus PAUD pada tingkat kabupaten/kota dilaksanakan oleh Dinas Pendidikan dan Bidang Pendidikan Nonformal Kabupaten/Kota yang menangani PAUD melalui kegiatan: (a) Melaksanakan pembinaan program di tingkat kecamatan; (b) Membantu menyampaikan informasi kepada masyarakat tentang pelaksanaan kegiatan pembinaan Gugus PAUD; (c) Mengkoordinasikan kerjasama dengan instansi/ 


\section{Jurnal Pendidikan dan Pemberdayaan Masyarakat, 4 (1), March 2017 - 47}

Ikka Kartika Abbas Fauzi

lembaga terkait untuk membina pelaksanaan pembinaan Gugus PAUD; (4) Pembinaan Gugus PAUD tingkat kecamatan dilaksanakan oleh UPTD (Unit Pelaksana Teknis Dinas), tanggung jawab administrasinya dilaksanakan secara teknis oleh Pengawas TK/SD, Kelompok Kerja Pendidik (KKG), Kelompok Kerja Kepala/Pengelola $\left(\mathrm{K}_{3} \mathrm{P}\right)$. Pengawas TK/SD merupakan penggerak maju mundurnya suatu gugus PAUD sehingga Gugus PAUD dapat difungsikan sebagaimana mestinya.

Ketiga, kebersamaan. Hal ini sangat diperlukan dalam penerapan lesson study karena model ini merupakan aktivitas peningkatan kompetensi guru melalui belajar sesama teman (peer learning), yang dilakukan secara terprogram, untuk mencari solusi terhadap kasus-kasus nyata yang dihadapi mereka di kelas, dengan tujuan agar guru dapat mengajar lebih profesional sehingga kegiatan pembelajaran lebih berkualitas. Menurut Lewis (2002, p. 1), "As we will see, lesson study is a cycle in which teachers work together to consider their long-term goals for students, bring those goals to life in actual "research lessons," and collaboratively observe, discuss, and refine the lessons.".

Salah satu diantara fungsi Gugus PAUD adalah sarana untuk saling bertukar informasi dan saling membelajarkan antar anggota dan anggota dengan lingkungan masyarakat. Fungsi ini menuntut adanya kebersamaan di antara para anggota gugus. Dalam Gugus PAUD kebersamaan antara pendidik TK, Pendidik Kober dan SPS PAUD dibangun agar keberadaan mereka bisa saling melengkapi dalam mengembangkan pendidikan bagi anak usia dini. Walaupun Gugus PAUD pada umumnya baru tumbuh sejak tahun 2012, namun beberapa diantaranya sudah mampu mengintegrasikan tiga kelompok pendidik tadi sehingga mereka bisa saling berbagi. Gugus PAUD tersebut sudah mampu memenuhi fungsi selaku wadah pembinaan professional dalam rangka meningkatkan kompetensi pendidik dan tenaga kependidikan PAUD.

Kebersamaan ini tumbuh antara lain karena berbagai upaya berikut ini: (1) para pendidik PAUD tergabung dalam asosiasi tenaga pendidik, seperti IGTKI dan
Himpaudi, sering mempertemukan masingmasing anggotanya dalam berbagai kegiatan yang sama; (2) para Pembina Gugus PAUD mendorong dilaksanakannya pertemuan rutin setiap bulan serta kegiatan-kegiatan rekreatif maupun lomba antar Gugus yang diselenggarakan mulai dari tingkat kabupaten/kota hingga tingkat nasional; (3) lokasi tempat kerja mereka berada dalam satu wilayah administrative yang sama dan tempat tinggalnya pun pada umumnya masih berada di wilayah yang sama sehingga kondisi social budayanya pun relative sama sehingga tidak mengalami kesulitan dalam berkomunikasi.

Keempat, pendekatan partisipatif. Dalam lesson study ada tahap identifikasi kebutuhan pendidik yang diangkat dari kasus-kasus nyata yang dihadapi di kelas. Hasil identifikasi kemudian didiskusikan bersama untuk menentukan tujuan lesson learning, selanjutnya direncanakan pelaksanaannya secara bersama pula. Dalam menetapkan kegiatan pembinaan, Gugus PAUD selalu mengacu pada kebutuhan pendidik PAUD yang ada di Gugus Inti, Gugus Imbas maupun pengurus Gugus PAUD. Di samping itu juga masukan dari pengurus PKG PAUD Kecamatan, Pengawas TK dan Penilik PAUD. Masukan dari ketiga pihak ini umumnya berkaitan dengan sosialisasi aturan pemerintah. Dalam pelaksanaannya, pengurus dan anggota gugus membahas bersama-sama program kerja gugus, pengembangan gugus, dan kekhususan yang dihadapinya, baik yang bersifat teknis edukatif, seperti penyusunan program pembelajaran, metode pembelajaran, pembuatan alat permainan edukatif, keanggotaan pendidik, akses fasiltas yang di danai pemerintah, pemda, lembaga, atau pihak terkait dan alat peraga lainnya.

Kelima, kemampuan bermitra. Beberapa diantara tujuan khusus Gugus PAUD adalah: (1) Optimalisasi sumber belajar, sarana/prasarana dan potensi lingkungan untuk peningkatan, pengembangan dan eksistensi anggota Gugus PAUD; (2) Peningkatan komunikasi yang efisien dan efektif antar anggota komunitas Gugus PAUD, Gugus dengan orang tua dan masyarakat; dan (3) Fasilitasi terhadap akses fasilitas sumber-sumber pembelajaran dari lingkung- 


\section{Jurnal Pendidikan dan Pemberdayaan Masyarakat, 4 (1), March 2017 - 48}

Ikka Kartika Abbas Fauzi

an dan pemerintah. Ini artinya Gugus PAUD harus terbuka untuk bermitra dengan pihakpihak yang memiliki kepedulian terhadap perkembangan PAUD atau memiliki potensi untuk meningkatkan kinerja pendidik PAUD. Hasil penelitian menunjukkan bahwa Gugus PAUD selama ini sudah biasa bermitra dengan berbagai pihak dalam rangka meningkatkan kompetensi pendidik PAUD dalam bidang-bidang yang menjadi garapan lembaga-lembaga tersebut.

Dalam lesson study kemampuan bermitra dibutuhkan, terutama saat prosesnya sedang berjalan biasanya diperlukan masukan dari para pakar atau tenaga akhli untuk meluruskan atau meningkatkan kinerja tim lesson study.

Keenam, penumbuhan komunitas belajar. Tujuan khusus Gugus PAUD diantaranya adalah menjadi wahana pembinaan pendidik dan tenaga kependidikan PAUD dalam hal pengembangan dan inovasi pembelajaran PAUD serta peningkatan profesionalisme pendidik dan tenaga kependidikan dalam rangka peningkatan mutu layanan anak usia dini sesuai dengan tahap perkembangannya. Tujuan ini menandakan bahwa Gugus PAUD dibangun untuk membentuk komunitas belajar melalui wadah yang teroganisir, artinya pihak pengurus maupun Pembina harus mampu mendorong atau mengkondisikan pendidik untuk terus menerus belajar dalam rangka menumbuhkan masyarakat gemar belajar (learning society). Melalui Gugus pendidik PAUD dapat berinteraksi dan berdiskusi secara cepat dalam mencari solusi terhadap permasalahan keseharian yang dihadapi disekolahnya. Ini artinya pendidik didorong untuk terus menerus melakukan perbaikan terhadap kompetensinya melalui aktivitas yang bermuatan edukatif. Terbukti dari hasil penelitian bahwa seluruh pendidik PAUD mengikuti kegiatan di Gugus PAUD dengan alasan ingin menambah pengetahuan atau wawasan baru karena ingin meningkatkan kompetensi. Beberapa diantaranya menambahkan alasan, yaitu ingin berbagi pengalaman.

Dalam lesson study, perbaikan atau peningkatan kualitas pembelajaran dapat tercapai dengan baik bila dilakukan secara berkesinambungan. Ini juga mengandung arti bahwa pendidik harus terus menerus belajar agar kualitas kinerjanya semakin meningkat.

\section{SIMPULAN DAN SARAN}

Fokus penelitian ini adalah untuk mencari potensi Gugus PAUD yang dapat menjadi peluang sebagai wadah pengembangan pembinaan pasca pelatihan pendidik PAUD dengan menggunakan model pembinaan lesson study. Ternyata potensi yang dimiliki Gugus PAUD sangat relevan dengan kondisi yang dibutuhkan bagi penerapan lesson study, yaitu pertama, wadah yang terstruktur dan terorganisir. Hal ini terlihat dari adanya struktur kepengurusan dan pembagian tugas yang jelas serta memiliki legalitas serta pengakuan dari pihak yang berwenang serta memiliki visi, misi, tujuan dan program yang jelas dan melaksanakan kegiatannya sesuai dengan langkah-langkah manajemen yang baik.

Kedua, kebersamaan. Ini terlihat dari kemampuan Gugus PAUD dalam mengintegrasikan tiga kelompok pendidik PAUD (pendidik TK, Pendidik Kober dan SPS PAUD) sehingga mereka bisa saling berbagi. Kebersamaan ini nampak juga dari upaya para pendidik untuk memperoleh kejelasan pengetahuan dan keterampilan yang diperoleh selama pelatihan dari lingkungannya, seperti kepada teman, kepada Ketua dan pengurus Gugus PAUD.

Ketiga, pendekatan partisipatif. Ini terlihat dari langkah Gugus PAUD dalam menetapkan kegiatan pembinaan selalu didasarkan pada kebutuhan pendidik yang ada di Gugus Inti maupun Gugus Imbas.

Keempat, kemampuan untuk bermitra. Ini terlihat dari kerjasamanya dengan berbagai pihak dalam rangka meningkatkan pengetahuan dan keterampilan pendidik PAUD.

Kelima, membangun komunitas belajar. Ini terlihat dari upaya Pembina serta pengurus Gugus PAUD secara rutin, minimal satu bulan sekali, melakukan aktivitas bermuatan edukatif. Hasilnya menunjukkan bahwa keikutsertaan pendidik PAUD dalam kegiatan di Gugus PAUD karena ingin menambah pengetahuan atau wawasan baru dalam upaya meningkatkan kompetensinya. 


\section{Jurnal Pendidikan dan Pemberdayaan Masyarakat, 4 (1), March 2017 - 49}

Ikka Kartika Abbas Fauzi

Bagi Gugus PAUD yang akan menerapkannya perlu disarankan hal-hal sebagai berikut agar hasilnya lebih optimal. Pertama, Pemerintah, sejak dari tingkat Pusat hingga tingkat Kecamatan mendorong pembentukan dan pengembangan Gugus PAUD serta melakukan pembinaan. Hal ini merupakan peluang bagi para pendidik PAUD, terutama pendidik PAUD non formal yang kualifikasi akademiknya banyak yang masih belum memadai, untuk memanfaatkannya secara optimal bagi peningkatan kompetensi dirinya. Namun ada dua hal penting yang perlu diingat, bahwa dorongan pemerintah, dalam hal ini Dinas Pendidikan Kabupaten/Kota beserta perangkatnya hingga tingkat Kecamatan, belum memberi dampak apapun bila tidak ditindaklanjuti dengan tindakan konkrit yang dilaksanakan secara konsisten melalui pendekatan yang tepat sesuai kondisi masing-masing daerah. Selanjutnya, para pengurus HIMPAUDI dan IGRA harus mampu menyamakan persepsinya serta mengintegrasikan kepentingan para anggotanya dalam wadah Gugus PAUD. Kedua pihak inilah yang akan menjadi pendukung dan pelaku utama berjalannya Gugus PAUD sesuai fungsinya.

Kedua, salah satu tujuan Gugus PAUD adalah memfasilitasi terhadap akses fasilitas sumber-sumber pembelajaran dari lingkungan dan pemerintah. Ini artinya Gugus PAUD harus terbuka melakukan kemitraan dengan berbagai pihak, pemerintah maupun non pemerintah, kelompok masyarakat maupun perorangan. Dalam penerapan lesson study, kemitraan dengan pihak-pihak yang memahami tentang pembelajaran di PAUD sangat diperlukan, misalnya dengan pendidik PAUD yang sudah senior (praktisi) atau dengan para ahli pendidikan dari perguruan tinggi.

Ketiga, Gugus PAUD maupun model Lesson Study mendorong tumbuhnya komunitas belajar, yang akan saling membelajarkan di antara Pendidik PAUD secara kolaboratif. Artinya, para pendidik PAUD yang terlibat sebagai anggota tim Lesson Study harus memiliki keinginan untuk belajar dan melakukan kegiatan secara kolaboratif. Ciri-ciri kegiatan kolaboratif adalah jika para pendidik PAUD bersama teman-temannya satu tim mampu menggali sendiri permasalahan yang ditemukan dalam kegiatan pembelajaran, mampu merencanakan pemecahan masalah yang dihadapinya, melaksanakan rencana pemecahan masalah , mengevaluasi hasilnya serta melakukan refleksi terhadap apa yang telah dilakukannya. Mungkin sebagai awal penerapan diperlukan para pendidik yang memiliki karakteristik tersebut, sehingga apa yang mereka lakukan mampu menginspirasi dan memotivasi teman-temannya yang lain untuk mencoba.

\section{DAFTAR PUSTAKA}

Asolihin. (2013). Sejarah sekolah PAUD di Indonesia, online: http://paudanakbermainbelajar.

blogspot. com/ 2013/o4/sejarah-pauddi-indonesia.html. tanggal 20 Agustus 2014.

Buckley, R., \& Caple, J. (2009). The theory and practice of training. London: Kogan Page.

Cerbin, B., \& Kopp, B. (2004). Lesson study for college teachers: An introduction. Retrieved March 23, 2017, from https://www.uwlax.edu/sotl/lsp/index 2.htm

Coombes, F. (2011). Successful selfmotivation. London: Hodder Education.

Depdiknas, Permendiknas no.58/2009 tentang Standar PAUD, Jakarta : Departemen Pendidikan Nasional

Depdiknas, Depag, JICA. (2009). Panduan untuk Lesson Study Berbasis MGMP dan Lesson Study Berbasis Sekolah. Jakarta: PELITA.

Depdiknas, Rencana Strategis Departemen Pendidikan Nasional Tahun 20052009, Menuju Pembangunan Pendidikan Nasional Jangka Panjang 2025. Jakarta: Depdiknas.

Depdiknas, Rencana Strategis (Renstra) Departemen Pendidikan Nasional tahun 2010-2014. Jakarta: Depdiknas

Direktorat PAUD, Ditjen PAUDNI Kemdiknas. Peraturan Menteri Pendidikan Nasional Republik Indonesia Nomor 58 tahun 2009 
tentang Standar Pendidikan Anak Usia Dini. Jakarta: Direktorat PAUD, Ditjen PAUDNI Kemdiknas.

Firman, H., \& Kaniawati, I. (2007). Monitoring $\mathcal{E}$ evaluasi program lesson study (Lesson learned dari JICASISTTEMS). Bandung: UPI Press.

Geeraerts, K., Tynjälä, P., Heikkinen, H. L. T., Markkanen, I., Pennanen, M., \& Gijbels, D. (2015). Peer-group mentoring as a tool for teacher development. European Journal of Teacher Education, 38(3), 358-377. http://doi.org/10.108o/02619768.2014.9 83068

IMSTEP-JICA. (2007). Lesson Study Suatu Strategi untuk Meningkatkan Keprofesionalan Pendidik. Bandung : UPI Press.

Kementerian Pendidikan Nasional .(2010). Peraturan Presiden Nomor 24 tahun 2010 yang disempurnakan Peraturan Presiden Nomor 67 Tahun 2010 tentang Perubahan Atas Peraturan Presiden Nomor 24 Tahun 2010 tentang Kedudukan, Tugas, dan Fungsi Kementrerian Negara serta Susunan Organisasi, Tugas, dan Fungsi Eselon I Kementerian Negara. Jakarta: Kemdiknas.

Kementerian Pendidikan Nasional .(2011). Pedoman Pembinaan Gugus Pendidikan Anak Usia Din. Jakarta: Direktorat Jenderal Pendidikan Anak Usia Dini Nonformal dan Informal Direktorat Pembinaan Pendidikan Anak Usia Dini.

Kementerian Pendidikan Nasional (2012). Undang-Undang Nomor 20 Tahun 2003 Tentang Sistem Pendidikan Nasional. Jakarta: Kementerian Pendidikan Nasional.

Kirkpatrick, D. L., \& Kirkpatrick, J. D. (2006). Evaluating training programs: The four levels. California: Berrett-Koehler.

Lewis, C. C. (2002). Lesson study: A handbook of teacher-led instructional change. Research for Better Schools, Inc. Retrieved from https://books.google.co.id/books/abou t/Lesson_Study.html?id=hBJKAAAAYA AJ\&redir_esc $=\mathrm{y}$

Mulyana, S, (2007), Lesson Study (Makalah), Bandung: LPMP-Jawa Barat

Muttaqin, F. (2011). Dampak pendidikan dan pelatihan dasar profesi terhadap peningkatan kompetensi pendidik PAUD. Skripsi, Bandung: FKIPUNINUS .

Republik Indonesia. (1950) Undang-UndangNomor 4 Tahun 1950 tentang dasardasar pendidikan-dan pengajaran. Retrived from: https:// www.scribd.com/doc/76840589/Unda ng-Undang-Nomor-4-Tahun-1950Tentang-Dasar-Dasar-PendidikanDan-Pengajaran

Riyati, S. (2007). Sistem pembinaan profesional guru pendidikan IPA melalui lesson study. Bandung.

Sudjana, D. (Djudju). (2001). Metode dan teknik pembelajaran partisipatif. Falah Production. Retrieved from https://books.google.co.id/books/abou t/Metode_dan_teknik_pembelajaran_p artisipa.html?id=YsAdAAAACAAJ\&red ir_esc $=y$

Sumarto, H. S. (2004). Inovasi, partisipasi dan good governance: 20 prakarsa inovatif dan partisipatif di Indonesia. Yogyakarta: Yayasan Obor.

Valerio, A., Parton, B., \& Robb, A. (2014). Entrepreneurship education and training programs around the world: Dimensions for success. Washington D.C.: The World Bank. http://doi.org/10.1596/978-1-46480202-7 